\title{
KINERJA PEMERIKSA PAJAK: TIGA VARIABEL PENJELAS PENCAPAIAN TARGET PAJAK OPTIMAL
}

\section{TAX AUDITORS PERFORMANCE: THREE VARIABLES EXPLAINING TOP TAX ACCOMPLISHMENT}

\author{
Santuo \\ Kantor Pelayanan Pajak Pratama Bulukumba - Direktorat Jenderal Pajak \\ email: santo.statistika@gmail.com
}

\begin{abstract}
Abstrak
Keberhasilan pemeriksaan pajak ditentukan oleh kinerja pemeriksa pajak. Oleh karena itu, untuk mencapai hasil pemeriksaan yang optimal, diperlukan adanya upaya untuk meningkatkan kinerja pemeriksa pajak. Kinerja pemeriksa pajak dipengaruhi oleh beberapa faktor, beberapa diantaranya adalah profesionalisme, pengalaman kerja dan komitmen organisasi dari pemeriksa pajak. Beberapa penelitian sebelumnya mengemukakan hasil bahwa profesionalisme, pengalaman kerja dan komitmen organisasi berpengaruh terhadap kinerja pemeriksa pajak. Namun terdapat juga penelitian sebelumnya yang mengemukakan hasil bahwa profesionalisme, pengalaman kerja dan komitmen organisasi tidak berpengaruh terhadap kinerja pemeriksa pajak. Penelitian ini bertujuan untuk mengetahui pengaruh profesionalisme, pengalaman kerja dan komitmen organisasi terhadap kinerja pemeriksa pajak pada Kantor Pelayanan Pajak Pratama Bulukumba. Populasi penelitian yaitu sebanyak 37 pemeriksa pajak yang terdiri atas fungsional pemeriksa pajak dan petugas pemeriksa pajak pada Kantor Pelayanan Pajak Pratama Bulukumba. Jumlah sampel ditentukan dengan teknik total sampling, yaitu dengan mengambil semua populasi yaitu sebanyak 37 responden. Teknik pengumpulan data menggunakan kuesioner. Analisis data menggunakan analisis regresi linear berganda dengan uji hipotesis parsial dan simultan. Hasil penelitian menunjukkan bahwa terdapat pengaruh yang positif dan signifikan pada profesionalisme, pengalaman kerja dan komitmen organisasi terhadap kinerja pemeriksa pajak. Hal ini berarti bahwa kinerja pemeriksa pajak pada Kantor Pelayanan Pajak Pratama Bulukumba secara mayoritas dipengaruhi oleh profesionalisme, pengalaman kerja dan komitmen organisasi pemeriksa pajak serta selebihnya dipengaruhi oleh faktor lain yang tidak dimasukkan dalam model penelitian ini.
\end{abstract}

Kata Kunci: Pemeriksa Pajak, Kinerja, Profesionalisme, Pengalaman Kerja, Komitmen Organisasi

\begin{abstract}
Tax audit success is determined by performance of tax auditors. Therefore, to achieve optimal tax audit results, some efforts are needed to increase performance of tax auditors. Performance of tax auditors is influenced by several factors, including professionalism, work experience and organizational commitment of tax auditors. Several previous studies have shown that professionalism, work experience and organizational commitment influence performance of tax auditors. But there are also some previous studies show professionalism, work experience and organizational commitment do not influence performance of tax auditors. This study aims to determine the effect of including professionalism, work experience and organizational commitment on performance of tax auditors at Bulukumba Small Tax Office. The Population of this study are 37 tax auditors at Bulukumba Small Tax Office. The number of samples is determined by total sampling technique, which is taking all the population of 37 respondents. The data collection technique is questionnaire. Data analysis used is through multiple linear regression analysis with partial and simultaneous hypothesis tests. The results indicate that there is a positive and significant influence on professionalism, work experience and organizational commitment to performance of tax auditors. This means that performance of tax auditors a Bulukumba Tax Office is generally influenced by professionalism, work experience and organizational commitment of tax auditors and the others is influenced by other factors not included in this research model.
\end{abstract}

Keywords: Tax Auditor, Performance, Professionalism, Work Experience, Organizational Commitment 


\section{PENDAHULUAN}

Pajak merupakan salah satu sumber utama penerimaan negara. Pajak adalah kontribusi wajib kepada negara yang terutang oleh orang pribadi atau badan yang bersifat memaksa berdasarkan undang-undang, dengan tidak mendapatkan imbalan secara langsung dan digunakan untuk keperluan negara bagi sebesar-besarnya kemakmuran rakyat (UU 28 Tahun 2007). Sebagai salah satu sumber penerimaan negara, pajak memiliki peranan yang cukup besar dalam berlangsungnya pembangunan yang dilaksanakan oleh pemerintah, baik pemerintah pusat maupun pemerintah daerah.

Sistem perpajakan yang berlaku di Indonesia adalah self assessment system. Menurut Ibrahim dan Arum (2018), self assessment system memberikan kepercayaan kepada wajib pajak untuk bertanggung jawab dalam menetapkan kewajiban pajaknya dan kemudian secara akurat dan tepat waktu membayar dan melaporkan pajak tersebut. Dengan kata lain, wajib pajak menetukan sendiri besarnya pajak yang terutang. Dalam pelaksanaan self assessment system, pemerintah melalui Direktorat Jendral Pajak memiliki peran untuk melakukan pengawasan, pelayanan, pembinaan serta sanksi perpajakan. Pengawasan ini dilakukan untuk mengetahui apakah wajib pajak yang diberi kewenangan melalui self assessment system patuh dan tidak melakukan kecurangan. Pengawasan tersebut dilakukan salah satunya melalui adanya pemeriksaan pajak (Faries dan Budiono, 2014). Pemeriksaan pajak adalah serangkaian kegiatan menghimpun serta mengolah data, keterangan, dan bukti yang dilaksanakan secara objektif serta profesional berdasarkan standar pemeriksaan untuk menguji kepatuhan pemenuhan kewajiban perpajakan (Undang-Undang Nomor 28 Tahun 2007).

Arwati dan Hanifah (2010) dalam penelitiannya menyatakan bahwa keberhasilan pemeriksaan pajak merupakan salah satu juru kunci untuk meningkatkan penerimaan pajak. Sedangkan keberhasilan pemeriksaan pajak ini dapat dinilai dari kinerja pemeriksa pajak itu sendiri. Oleh karena itu, untuk mencapai hasil pemeriksaan pajak yang optimal, diperlukan adanya upaya untuk meningkatkan kinerja pemeriksa pajak.

Kinerja pemeriksa pajak merupakan hasil penelitian atas perilaku pemeriksa pajak dalam melaksanakan peran yang mereka mainkan dalam organisasi untuk mencapai prestasi hasil pemeriksa pajak (Misral dan Pratama, 2018). Menurut Leatemia (2018), kinerja merupakan hasil kerja yang dicapai oleh seorang pegawai dalam melaksanakan tugas-tugas yang dibebankan kepadanya sesuai dengan tanggung jawab yang diberikan kepadanya, yang didasarkan pada kecakapan, pengalaman dan keunggulan serta waktu dengan output yang dihasilkan tercermin dengan baik. Kinerja juga merupakan suatu pencapaian persyaratan pekerjaan tertentu yang akhirnya secara langsung dapat 
tercermin dari output yang dihasilkan baik kuantitas maupun kualitas. Menurut Moeheriono (2012), kinerja atau performance merupakan gambaran mengenai tingkat pencapaian pelaksanaan suatu program kegiatan atau kebijakan dalam mewujudkan sasaran, tujuan visi dan misi organisasi yang dituangkan melalui perencanaan suatu organisasi, kinerja yang dihasilkan oleh setiap orang memiliki pencapaian yang berbeda-beda sehingga tidak dapat disamakan dengan semua orang.

Terdapat beberapa faktor yang mempengaruhi kinerja pemeriksa pajak, salah satunya adalah profesionalisme pemeriksa pajak. Profesionalisme merupakan suatu komitmen yang terbentuk dari dalam seorang professional, tanpa paksaan dari siapapun dan secara sadar bertanggung jawab terhadap profesinya (Fatah et al., 2017). Menurut Waterkamp et al. (2017), pengaruh profesional seseorang sudah tentu akan berdampak pada kinerjanya. Faktor profesionalisme yang dikemukakan oleh Waterkamp et al. (2017) hanya menekankan pada profesionalisme pegawai yang diperoleh berdasarkan kepuasan kerja, sehingga hanya pegawai dengan kepuasan kerja tinggi yang akan akan berupaya meningkatkan kinerjanya. Sedangkan ada beberapa aspek dalam mengukur profesionalisme, tidak hanya terkait kepuasan kerja. Menurut Sedarmayanti (2010), ukuran profesionalisme adalah kompetensi, dan efesiensi serta bertanggung jawab. Dalam penelitiannya, Yobi dan Putra (2017) menyatakan bahwa profesionalisme pegawai berpengaruh secara signifikan terhadap kinerja pegawai. Hal ini diperkuat oleh Faries dan $\mathrm{Bu}-$ diono (2014) yang menyatakan bahwa profesionalisme pegawai akan meningkatkan kinerja pegawai. Hasil penelitian yang berbeda dikemukakan oleh Avianda (2014) bahwa profesionalisme tidak mempunyai pengaruh secara signifikan terhadap kinerja karyawan. Dengan demikian, dapat dikatakan bahwa profesionalisme dapat berpengaruh maupun tidak berpengaruh terhadap kinerja pemeriksa pajak.

Faktor lain yang mempengaruhi kinerja pemeriksa pajak adalah pengalaman kerja pemeriksa pajak. Pengalaman kerja adalah tingkat penguasaan pengetahuan serta keterampilan seseorang dalam pekerjaan yang dapat diukur dari masa kerja dan dari tingkat pengetahuan dan keterampilan yang dimiliki (Bili et al.,2018). Ratulangi dan Soegoto (2016) menyatakan bahwa pengalaman kerja berpengaruh terhadap kinerja pegawai. Dalam penelitiannya, Paat et al. (2019) menyatakan bahwa salah satu faktor yang mempengaruhi kinerja karyawan adalah pengalaman kerja karyawan. Hal ini diperkuat oleh Leatemia (2018) yang menyatakan bahwa pengalaman kerja yang banyak akan dapat menunjang kinerja pegawai. Hasil penelitian yang berbeda dikemukakan oleh Siahaan (2015) bahwa pengalaman kerja tidak mempunyai pengaruh 
secara signifikan terhadap kinerja pemeriksa pajak. Dengan demikian, dapat dikatakan bahwa pengalaman kerja dapat berpengaruh maupun tidak berpengaruh terhadap kinerja pemeriksa pajak.

Kinerja pemeriksa pajak juga dipengaruhi oleh faktor lainnya, salah satunya adalah komitmen organisasi pemeriksa pajak. Suparyadi (2015) menyatakan bahwa komitmen organisasi merupakan sikap yang menunjukkan lebih dari sekedar keanggotaan formal, tetapi juga meliputi sikap menyukai organisasi dan kesediaan untuk mengusahakan tingkat upaya yang tinggi bagi kepentingan organisasi demi mencapai tujuannya. Berdasarkan definisi ini, dalam komitmen organisasi tercakup unsur loyalitas terhadap perusahaan, keterlibatan dalam pekerjaan, dan identifikasi terhadap nilai-nilai dan tujuan perusahaan. Karyawan yang menunjukkan komitmen organisasinya, ada keinginan untuk memberikan tenaga dan tanggung jawab untuk kesejahteraan dan keberhasilan organisasi atau perusahaan tersebut. Karyawan yang memiliki komitmen organisasional cenderung setia dalam organisasi, bangga terhadap organisasi, mengikuti kebijakan organisasi sehingga kinerja yang dihasilkan cukup baik (Nurhaida dan Susilastri, 2019). Dalam penelitiannya, Yobi dan Putra (2017) menyatakan bahwa komitmen organisasi pegawai berpengaruh secara signifikan terhadap kinerja pegawai. Hal ini diperkuat oleh Respatiningsih dan Sudirjo
(2015) yang menyatakan bahwa komitmen organisasi berpengaruh secara signifikan terhadap kinerja pegawai. Hasil penelitian yang berbeda dikemukakan oleh Desiyanti et al. (2019) bahwa komitmen organisasi tidak mempunyai pengaruh secara signifikan terhadap kinerja pegawai. Dengan demikian, dapat dikatakan bahwa komitmen organisasi dapat berpengaruh maupun tidak berpengaruh terhadap kinerja pemeriksa pajak.

Kantor Pelayanan Pajak Pratama Bulukumba merupakan salah satu unit kerja Direktorat Jenderal Pajak Kementerian Keuangan Republik Indonesia, yang berada langsung di bawah Kantor Wilayah Direktorat Jenderal Pajak Sulawesi Selatan, Barat dan Tenggara. Kantor Pelayanan Pajak Pratama Bulukumba memiliki tugas dan tanggung jawab salah satunya untuk melaksanakan pengadministrasian perpajakan wajib pajak yang berada di wilayah Kabupaten Bulukumba, Kabupaten Sinjai dan Kabupaten Kepulauan Selayar. Pelaksanaan pemeriksaan pajak pada Kantor Pelayanan Pajak Pratama Bulukumba dilaksanakan oleh pemeriksa pajak yang terdiri atas fungsional pemeriksa pajak dan petugas pemeriksa pajak.

Berdasarkan uraian latar belakang permasalahan di atas, maka tujuan penelitian ini adalah untuk mengetahui pengaruh profesionalisme pemeriksa pajak secara parsial terhadap kinerja pemeriksa pajak, pengaruh pengalaman kerja pemeriksa pajak secara parsial terhadap 
kinerja pemeriksa pajak, pengaruh komitmen organisasi pemeriksa pajak secara parsial terhadap kinerja pemeriksa pajak, pengaruh profesionalisme, serta pengalaman kerja dan komitmen organisasi pemeriksa pajak secara simultan terhadap kinerja pemeriksa pajak pada Kantor Pelayanan Pajak Pratama Bulukumba.

\section{METODE PENELITIAN}

Penelitian ini menggunakan metode penelitian eksplanatori, yang merupakan suatu metode penelitian yang digunakan untuk mengetahui hubungan kausal antar variabel melalui pengujian hipotesis.

Populasi dalam penelitian ini adalah seluruh pemeriksa pajak yang terdiri atas fungsional pemeriksa pajak dan petugas pemeriksa pajak pada Kantor Pelayanan Pajak Pratama Bulukumba sejumlah 37 responden. Teknik pengambilan sampel dalam penelitian ini menggunakan teknik total sampling, yaitu pengambilan sampel yang sama dengan jumlah populasi yang ada (Arikunto, 2002). Jumlah sampel yaitu sebanyak 37 responden.

Metode pengumpulan data dalam penelitian ini adalah menggunakan instrumen kuesioner, yaitu pengumpulan data dengan menyebarkan kuesioner dengan daftar pernyataan tertutup yang diberikan kepada responden. Pengumpulan data menggunakan periode waktu cross section, dimana penelitian berlangsung selama bulan Juni tahun 2019.
Variabel yang digunakan dalam penelitian ini adalah sebagai berikut:

1. Variabel bebas yaitu profesionalisme pemeriksa pajak, pengalaman kerja pemeriksa pajak dan komitmen organisasi pemeriksa pajak sebagai variabel $\mathrm{X}_{1}$, variabel $\mathrm{X}_{2}$ dan variabel $\mathrm{X}_{3}$.

2. Variabel terikat yaitu kinerja pemeriksa pajak sebagai variabel Y.

Masing-masing indikator dari setiap variabel dalam penelitian ini dituangkan dalam pertanyaan atau pertanyaan yang diukur menggunakan skala likert, yaitu setiap pertanyaan atau pernyataan dari setiap variabel diberi nilai skor dari yang terendah hingga tertinggi secara berturut-turut diberikan nilai 1, 2, 3, 4, 5. Pengujian kualitas instrument masing-masing variabel bebas dan variabel terikat dalam penelitian ini menggunakan uji validitas dan uji realibilitas.

Metode yang digunakan untuk melakukan analisa data dalam penelitian ini menggunakan metode regresi. Untuk menghindari terjadinya beberapa masalah asumsi klasik dalam model regresi, maka perlu dilakukan uji asumsi klasik. Uji asumsi klasik digunakan untuk memberikan kepastian bahwa persamaan regresi yang didapatkan dalam penelitian ini memiliki ketepatan dalam estimasi, tidak bias dan konsisten. Adapun uji asumsi klasik yang digunakan yaitu uji normalitas, uji multikolinieritas, uji autokorelasi dan uji heteroskedastisitas. 
Untuk menguji pengaruh profesionalisme pemeriksa pajak, pengalaman kerja pemeriksa pajak dan komitmen organisasi pemeriksa pajak terhadap kinerja pemeriksa pajak, digunakan analisis regresi linier berganda. Pengujian hipotesis dalam penelitian ini dilakukan dengan menggunakan uji parsial dengan uji t, uji simultan dengan uji $F$ dan uji koefisien determinasi dengan koefisien determinasi $\left(\mathrm{R}^{2}\right)$.

\section{HASIL PENELITIAN}

Informasi mengenai karakteristik variabel dalam penelitian dapat dilihat dalam tabel berikut:

\section{Tabel 1. Hasil Uji Statistik Deskriftif}

\begin{tabular}{cccccc}
\hline $\begin{array}{c}\text { Vari- } \\
\text { abel }\end{array}$ & N & Min & Max & Mean & $\begin{array}{c}\text { Std. } \\
\text { Deviasi }\end{array}$ \\
\hline X1 & 37 & 15 & 25 & 19,86 & 2,879 \\
X2 & 37 & 18 & 30 & 23,68 & 2,709 \\
X3 & 37 & 15 & 25 & 20,14 & 3,284 \\
Y & 37 & 29 & 40 & 33,78 & 2,800 \\
\hline
\end{tabular}

Sumber: Hasil Pengolahan Data 2019

Tabel 1 menunjukkan bahwa variabel profesionalisme pemeriksa pajak $\left(\mathrm{X}_{1}\right)$ memiliki nilai minimum sebesar 15 , nilai maksimum sebesar 25, rata-rata atau mean sebesar 19,86 dan standar deviasi sebesar 2,879. Hal ini menunjukkan bahwa terjadi perbedaan nilai profesionalisme pemeriksa pajak yang diteliti dengan nilai rata-ratanya sebesar 2,879. Variabel pengalaman kerja pemeriksa pajak $\left(\mathrm{X}_{2}\right)$ memiliki nilai minimum sebesar 18 , nilai maksimum sebesar 30, rata-rata atau mean sebesar 23,68 dan standar deviasi sebesar
2,709. Hal ini menunjukkan bahwa terjadi perbedaan nilai pengalaman kerja pemeriksa pajak yang diteliti dengan nilai rata-ratanya sebesar 2,709. Variabel komitmen organisasi pemeriksa pajak $\left(\mathrm{X}_{3}\right)$ memiliki nilai minimum sebesar 15 , nilai maksimum sebesar 25 , ratarata atau mean sebesar 20,14 dan standar deviasi sebesar 3,284. Hal ini menunjukkan bahwa terjadi perbedaan nilai komitmen organisasi pemeriksa pajak yang diteliti dengan nilai rataratanya sebesar 3,284. Variabel kinerja pemeriksa pajak (Y) memiliki nilai minimum sebesar 29, nilai maksimum sebesar 40, ratarata atau mean sebesar 33,78 dan standar deviasi sebesar 2,800. Hal ini menunjukkan bahwa terjadi perbedaan nilai kinerja pemeriksa pajak yang diteliti dengan nilai rata-ratanya sebesar 2,800 .

Hasil uji validitas terhadap variabel bebas adalah sebagai berikut:

Tabel 2. Hasil Uji Validitas Variabel Profesionalisme Pemeriksa Pajak

\begin{tabular}{cccc}
\hline $\begin{array}{c}\text { Item Per- } \\
\text { tanyaan }\end{array}$ & $\begin{array}{c}\text { Nilai Pear- } \\
\text { son Corre- } \\
\text { lation }\end{array}$ & $\begin{array}{c}\text { Nilai r } \\
\text { tabel }\end{array}$ & $\begin{array}{c}\text { Kesim- } \\
\text { pulan }\end{array}$ \\
\hline $\mathbf{X 1 . 1}$ & 0,681 & 0,275 & Valid \\
$\mathbf{X 1 . 2}$ & 0,813 & 0,275 & Valid \\
$\mathbf{X 1 . 3}$ & 0,882 & 0,275 & Valid \\
$\mathbf{X 1 . 4}$ & 0,866 & 0,275 & Valid \\
$\mathbf{X 1 . 5}$ & 0,751 & 0,275 & Valid \\
\hline
\end{tabular}

Sumber: Hasil Pengolahan Data 2019

Tabel 3. Hasil Uji Validitas Variabel Pengalaman Kerja Pemeriksa Pajak

\begin{tabular}{cccc}
\hline $\begin{array}{c}\text { Item Per- } \\
\text { tanyaan }\end{array}$ & $\begin{array}{c}\text { Nilai Pear- } \\
\text { son Corre- } \\
\text { lation }\end{array}$ & $\begin{array}{c}\text { Nilai r } \\
\text { tabel }\end{array}$ & $\begin{array}{c}\text { Kesim- } \\
\text { pulan }\end{array}$ \\
\hline $\mathbf{X 2 . 1}$ & 0,597 & 0,275 & Valid \\
$\mathbf{X 2 . 2}$ & 0,669 & 0,275 & Valid \\
\hline
\end{tabular}




\begin{tabular}{llll} 
X2.3 & 0,727 & 0,275 & Valid \\
X2.4 & 0,682 & 0,275 & Valid \\
X2.5 & 0,577 & 0,275 & Valid \\
X2.6 & 0,688 & 0,275 & Valid \\
\hline
\end{tabular}

Sumber: Hasil Pengolahan Data 2019

\begin{tabular}{cccc}
\multicolumn{4}{c}{ Tabel 4. Hasil Uji Validitas Variabel } \\
Komitmen Organisasi Pemeriksa & Pajak \\
\hline $\begin{array}{c}\text { Item Per- } \\
\text { tanyaan }\end{array}$ & $\begin{array}{c}\text { Nilai Pear- } \\
\text { son Corre- } \\
\text { lation }\end{array}$ & $\begin{array}{c}\text { Nilai r } \\
\text { tabel }\end{array}$ & $\begin{array}{c}\text { Kesim- } \\
\text { pulan }\end{array}$ \\
\hline X3.1 & 0,829 & 0,275 & Valid \\
$\mathbf{X 3 . 2}$ & 0,877 & 0,275 & Valid \\
$\mathbf{X 3 . 3}$ & 0,868 & 0,275 & Valid \\
$\mathbf{X 3 . 4}$ & 0,825 & 0,275 & Valid \\
$\mathbf{X 3 . 5}$ & 0,850 & 0,275 & Valid \\
\hline
\end{tabular}

Sumber: Hasil Pengolahan Data 2019

Berdasarkan tabel 2, tabel 3, dan tabel 4, diperoleh gambaran bahwa uji instrumen untuk variabel bebas, yaitu profesionalisme pemeriksa pajak $\left(\mathrm{X}_{1}\right)$, pengalaman kerja pemeriksa pajak $\left(\mathrm{X}_{2}\right)$ dan komitmen organisasi pemeriksa pajak $\left(\mathrm{X}_{3}\right)$ menunjukkan bahwa nilai pearson correlation untuk masing-masing item pertanyaan lebih besar dari nilai r-tabel yaitu 0,275 , sehingga bisa disimpulkan bahwa semua pertanyaan yang digunakan sebagai instrumen untuk variabel bebas adalah valid.

Hasil uji validitas terhadap variabel terikat dapat dilihat pada tebel 5. Berdasarkan tabel 5 diperoleh gambaran bahwa uji instrumen untuk variabel terikat, yaitu kinerja pemeriksa pajak (Y) menunjukkan bahwa nilai pearson correlation untuk masing-masing butir pernyataan lebih besar dari nilai r-tabel yaitu 0,275 , sehingga bisa disimpulkan bahwa semua pertanyaan yang digunakan sebagai instrumen untuk variabel terikat adalah valid.
Tabel 5. Hasil Uji Validitas Variabel Kinerja Pemeriksa Pajak

\begin{tabular}{cccc}
$\begin{array}{c}\text { Item Per- } \\
\text { tanyaan }\end{array}$ & $\begin{array}{c}\text { Nilai Pearson } \\
\text { Correlation }\end{array}$ & $\begin{array}{c}\text { Nilai } \mathbf{r} \\
\text { tabel }\end{array}$ & $\begin{array}{c}\text { Kesim- } \\
\text { pulan }\end{array}$ \\
\hline Y.1 & 0,404 & 0,275 & Valid \\
Y.2 & 0,580 & 0,275 & Valid \\
Y.3 & 0,776 & 0,275 & Valid \\
Y.4 & 0,645 & 0,275 & Valid \\
Y.5 & 0,713 & 0,275 & Valid \\
Y.6 & 0,566 & 0,275 & Valid \\
Y.7 & 0,641 & 0,275 & Valid \\
Y.8 & 0,532 & 0,275 & Valid \\
\hline
\end{tabular}

Sumber: Hasil Pengolahan Data 2019

Hasil uji reliabilitas terhadap variabel bebas dan variabel terikat adalah sebagai berikut:

\section{Tabel 6. Hasil Uji Realibiltas}

\begin{tabular}{lccc}
\hline \multicolumn{1}{c}{ Variabel } & $\begin{array}{c}\text { Nilai } \\
\text { Cronbach's } \\
\text { Alpha }\end{array}$ & $\begin{array}{c}\text { Nilai } \\
\text { Batas } \\
\text { Alpha }\end{array}$ & $\begin{array}{c}\text { Kesim- } \\
\text { pulan }\end{array}$ \\
\hline $\begin{array}{l}\text { Profesionalisme } \\
\text { Pemeriksa }\end{array}$ & 0,855 & 0,6 & Reliabel \\
Pajak & & & \\
\hline $\begin{array}{l}\text { Pengalaman } \\
\text { Kerja }\end{array}$ & 0,733 & 0,6 & Reliabel \\
$\begin{array}{l}\text { Pemeriksa } \\
\text { Pajak }\end{array}$ & & & \\
\hline $\begin{array}{l}\text { Komitmen } \\
\text { Organisasi }\end{array}$ & 0,904 & 0,6 & Reliabel \\
$\begin{array}{l}\text { Pemeriksa } \\
\text { Pajak }\end{array}$ & & & \\
\hline $\begin{array}{l}\text { Kinerja } \\
\text { Pemeriksa }\end{array}$ & 0,762 & 0,6 & Reliabel \\
Pajak & & & \\
\hline
\end{tabular}

Sumber: Hasil Pengolahan Data 2019

Hasil pengujian reabilitas dari masingmasing variabel sebagaiamana terlihat pada tabel 6 menunjukkan bahwa nilai cronbach's alpha untuk masing-masing variabel bebas maupun variabel terikat lebih besar dari nilai batas alpha yaitu 0,6, sehingga bisa disimpulkan bahwa seluruh instrumen yang digunakan 
untuk mengukur seluruh item dari variabel bebas yaitu profesionalisme pemeriksa pajak $\left(\mathrm{X}_{1}\right)$, pengalaman kerja pemeriksa pajak $\left(\mathrm{X}_{2}\right)$ dan kinerja organisasi pemeriksa pajak $\left(\mathrm{X}_{3}\right)$ serta variabel terikat yaitu kinerja pemeriksa pajak (Y) dinyatakan reliabel.

Hasil dari uji asumsi klasik adalah sebagai berikut:

\section{Tabel 7. Hasil Uji Normalitas}

\begin{tabular}{cccc}
\hline Model & $\begin{array}{c}\text { Kolmogorov- } \\
\text { Smirnov Z }\end{array}$ & $\begin{array}{c}\text { Asymp.Sig } \\
\text { (2-tailed) }\end{array}$ & Alpha \\
\hline 1 & 0,101 & 0,200 & 0,05 \\
\hline
\end{tabular}

Sumber: Hasil Pengolahan Data 2019

Hasil uji normalitas berdasarkan tabel 7 menunjukkan bahwa nilai kolmogorov-smirnov $z$ sebesar 0,101 dan nilai asymp.sig sebesar 0,200. Dari hasil tersebut diperoleh bahwa nilai asymp.sig lebih besar dari alpha yaitu 0,200 lebih besar dari 0,05, sehingga dapat disimpulkan bahwa model regresi dalam penelitian ini berdistribusi normal.

Hasil uji multikolinieritas berdasarkan tabel 8 menunjukkan bahwa untuk masingmasing variabel bebas, nilai VIF lebih kecil dari 10 dan nilai tolerance lebih besar dari 0,1. Hal ini berarti bahwa antara variabel bebas dalam penelitian ini tidak terjadi hubungan atau tidak memiliki hubungan satu sama lainnya, sehingga dapat disimpulkan bahwa tidak terdapat multikolinieritas antar variabel bebas dalam model regresi.

\section{Tabel 8. Hasil Uji Multikolinieritas}

\begin{tabular}{lcc}
\hline \multicolumn{1}{c}{ Variabel } & Tolerance & VIF \\
\hline $\begin{array}{l}\text { Profesionalisme } \\
\text { Pemeriksa Pajak }\end{array}$ & 0,950 & 1,053 \\
$\begin{array}{l}\text { Pengalaman Kerja } \\
\text { Pemeriksa Pajak }\end{array}$ & 0,972 & 1,029 \\
$\begin{array}{l}\text { Komitmen Organisasi } \\
\text { Pemeriksa Pajak }\end{array}$ & 0,976 & 1,024 \\
\hline \multicolumn{3}{c}{ Sumber: Hasil Pengolahan Data 2019} \\
\multicolumn{2}{l}{ Hasil uji autokorelasi berasarkan tabel 9}
\end{tabular}
menunjukkan bahwa nilai runs test sebesar 1,339 dan nilai asymp.sig sebesar 0,180. Dari hasil tersebut diperoleh bahwa nilai asymp.sig lebih besar dari alpha yaitu 0,180 lebih besar dari 0,05. Dengan demikian, dapat disimpulkan bahwa tidak terjadi autokorelasi pada model regresi dalam penelitian ini.

\section{Tabel 9. Hasil Uji Autokorelasi}

\begin{tabular}{cccc}
\hline Model & Runs Test & $\begin{array}{c}\text { Asymp.Sig } \\
\text { (2-tailed) }\end{array}$ & Alpha \\
\hline $\mathbf{1}$ & 1,339 & 0,180 & 0,05 \\
\hline \multicolumn{4}{l}{ Sumber: Hasil Pengolahan Data 2019}
\end{tabular}

Sumber: Hasil Pengolahan Data 2019

Tabel 10. Hasil Uji Heteroskedastisitas

\begin{tabular}{|c|c|c|}
\hline Variabel & $\mathbf{t}$ & sig \\
\hline (Konstanta) & $-0,512$ & 0,612 \\
\hline Profesionalisme & 1,087 & 0,285 \\
\hline Pemeriksa Pajak & & \\
\hline Pengalaman Kerja & 0,379 & 0,707 \\
\hline Pemeriksa Pajak & & \\
\hline Komitmen Organisasi & 0,624 & 0,537 \\
\hline \multicolumn{3}{|c|}{ Sumber: Hasil Pengolahan Data 2019} \\
\hline \multicolumn{3}{|c|}{ Hasil uji heteroskedastisitas berdasarkan } \\
\hline \multirow{3}{*}{\multicolumn{3}{|c|}{$\begin{array}{l}\text { tabel } 10 \text { menunjukkan bahwa nilai sig pada } \\
\text { masing-masing variabel bernilai lebih besar }\end{array}$}} \\
\hline & & \\
\hline & & \\
\hline ahwa tidak & & \\
\hline
\end{tabular}


Berdasarkan hasil uji asumsi klasik dapat disimpulkan bahwa model regresi dalam penelitian ini memenuhi seluruh kriteria pengujian asumsi klasik, sehingga bisa dilanjutkan ke uji regresi linier berganda.

Hasil uji regresi linier berganda terhadap ketiga variabel bebas, yaitu profesionalisme pemeriksa pajak $\left(\mathrm{X}_{1}\right)$, pengalaman kerja pemeriksa pajak $\left(\mathrm{X}_{2}\right)$ dan komitmen organisasi pemeriksa pajak $\left(\mathrm{X}_{3}\right)$ dapat dilihat pada tabel berikut:

\section{Tabel 11. Hasil Pengujian Regresi Linier}

\section{Berganda}

\begin{tabular}{|c|c|c|c|}
\hline \multirow{2}{*}{ Variabel } & \multirow[t]{2}{*}{ B } & \multicolumn{2}{|c|}{ Uji t } \\
\hline & & t hitung & sig \\
\hline (Konstanta) & 4,389 & 2,494 & 0,018 \\
\hline $\begin{array}{l}\text { Profesional- } \\
\text { isme } \\
\text { Pemeriksa } \\
\text { Pajak }\end{array}$ & 0,209 & 3,889 & 0,000 \\
\hline $\begin{array}{l}\text { Pengalaman } \\
\text { Kerja } \\
\text { Pemeriksa } \\
\text { Pajak }\end{array}$ & 0,569 & 10,089 & 0,000 \\
\hline $\begin{array}{l}\text { Komitmen } \\
\text { Organisasi } \\
\text { Pemeriksa } \\
\text { Pajak }\end{array}$ & 0,584 & 12,585 & 0,000 \\
\hline & \multicolumn{2}{|c|}{ Uji F } & $\mathbf{R}^{2}$ \\
\hline & F hitung & sig & \\
\hline & 104,085 & 0,000 & 0,904 \\
\hline
\end{tabular}

Sumber: Hasil Pengolahan Data 2019

Tabel 11 menunjukkan nilai koefisien determinasi $\left(\mathrm{R}^{2}\right)$ sebesar 0,904, yang berarti bahwa ada pengaruh sebesar 0,904 atau 90,4\% dari variabel bebas, yaitu profesionalisme pemeriksa pajak $\left(\mathrm{X}_{1}\right)$, pengalaman kerja pemeriksa pajak $\left(\mathrm{X}_{2}\right)$ dan komitmen organisasi pemeriksa pajak $\left(\mathrm{X}_{3}\right)$ dalam menjelaskan variabel terikat yaitu kinerja pemeriksa pajak (Y), sedangkan sisanya sebesar 0,096 atau 9,6\% dijelaskan oleh variabel lainnya yang tidak diteliti dalam model penelitian ini.

Berdasarkan tabel 11 diperoleh bahwa persamaan regresi linier berganda untuk penelitian ini adalah sebagai berikut:

$\mathrm{Y}=4,389+0,209 \mathrm{X} 1+0,569 \times 2+0,584 \times 3$

Dari persamaan regresi tersebut, diperoleh bahwa nilai koefisien regresi pada variabel profesionalisme pemeriksa pajak $\left(\mathrm{X}_{1}\right)$, pengalaman kerja pemeriksa pajak $\left(\mathrm{X}_{2}\right)$ dan komitmen organisasi pemeriksa pajak $\left(\mathrm{X}_{3}\right)$ semuanya positif, artinya semua variabel bebas berpengaruh positif terhadap variabel terikat. Nilai konstanta sebesar 4,389 dapat diartikan bahwa apabila nilai profesionalisme pemeriksa pajak $\left(\mathrm{X}_{1}\right)$, profesionalisme pemeriksa pajak $\left(\mathrm{X}_{2}\right)$ dan komitmen organisasi pemeriksa pajak $\left(\mathrm{X}_{3}\right)$ sama dengan nol, maka nilai kinerja pemeriksa pajak (Y) cenderung meningkat sebesar 4,389. Nilai koefisien dari $X_{1}$ sebesar 0,209 dapat diartikan bahwa apabilai nilai profesionalisme pemeriksa pajak $\left(\mathrm{X}_{1}\right)$ meningkat satu satuan, maka nilai kinerja pemeriksa pajak (Y) cenderung meningkat sebesar 0,209 satuan dengan asumsi variabel bebas lainnya memiliki nilai sama dengan nol. Nilai koefisien dari $\mathrm{X}_{2}$ sebesar 0,569 dapat diartikan bahwa apabilai nilai pengalaman kerja pemeriksa pajak $\left(\mathrm{X}_{2}\right)$ meningkat satu satuan, maka nilai kinerja pemeriksa pajak (Y) cenderung meningkat sebesar 0,569 satuan dengan asumsi variabel bebas lainnya memiliki nilai sama dengan nol. 
Nilai koefisien dari $\mathrm{X}_{3}$ sebesar 0,584 dapat diartikan bahwa apabilai nilai komitmen organisasi pemeriksa pajak $\left(\mathrm{X}_{3}\right)$ meningkat satu satuan, maka nilai kinerja pemeriksa pajak (Y) cenderung meningkat sebesar 0,584 satuan dengan asumsi variabel bebas lainnya memiliki nilai sama dengan nol.

\section{Pengujian Hipotesis Secara Parsial}

Perhitungan koefisien regresi secara parsial dapat dilihat pada tabel 11, dengan penjelasan sebagai berikut: variabel profesionalisme pemeriksa pajak $\left(\mathrm{X}_{1}\right)$ dengan kinerja pemeriksa pajak (Y) menunjukkan t-hitung sebesar 3,889 dengan angka sig sebesar 0,000. Karena angka sig lebih kecil dari alpha, yaitu 0,000 lebih kecil dari 0,05, hal ini berarti $\mathrm{H}_{0}$ ditolak dan $\mathrm{H}_{1}$ diterima, sehingga dapat disimpulkan bahwa profesionalisme pemeriksa pajak mempunyai pengaruh positif dan signifikan terhadap kinerja pemeriksa pajak pada Kantor Pelayanan Pajak Pratama Bulukumba.

Variabel pengalaman kerja pemeriksa pajak $\left(\mathrm{X}_{2}\right)$ dengan kinerja pemeriksa pajak (Y) menunjukkan t-hitung sebesar 10,089 dengan angka sig sebesar 0,000. Karena angka sig lebih kecil dari alpha, yaitu 0,000 lebih kecil dari 0,05, hal ini berarti $\mathrm{H}_{0}$ ditolak dan $\mathrm{H}_{1}$ diterima, sehingga dapat disimpulkan bahwa pengalaman kerja pemeriksa pajak mempunyai pengaruh positif dan signifikan terhadap kinerja pemeriksa pajak pada Kantor Pelayanan Pajak Pratama Bulukumba.
Variabel komitmen organisasi pemeriksa pajak $\left(\mathrm{X}_{3}\right)$ dengan kinerja pemeriksa pajak $(\mathrm{Y})$ menunjukkan t-hitung sebesar 12,585 dengan angka sig sebesar 0,000. Karena angka siglebih kecil dari alpha, yaitu 0,000 lebih kecil dari 0,05, hal ini berarti $\mathrm{H}_{0}$ ditolak dan $\mathrm{H}_{1}$ diterima, sehingga dapat disimpulkan bahwa komitmen organisasi pemeriksa pajak mempunyai pengaruh positif dan signifikan terhadap kinerja pemeriksa pajak pada Kantor Pelayanan Pajak Pratama Bulukumba.

2. Pengujian Hipotesis Secara Simultan

Tabel 11 menunjukkan bahwa nilai F-hitung sebesar 104,085 dengan angka sig sebesar 0,000. Karena angka sig lebih kecil dari alpha, yaitu 0,000 lebih kecil dari 0,05, hal ini berarti $\mathrm{H}_{0}$ ditolak dan $\mathrm{H}_{1}$ diterima, sehingga dapat disimpulkan bahwa profesionalisme pemeriksa pajak, pengalaman kerja pemeriksa pajak dan komitmen organisasi pemeriksa pajak secara bersama-sama mempunyai pengaruh positif dan signifikan terhadap kinerja pemeriksa pajakpada Kantor Pelayanan Pajak Pratama Bulukumba.

\section{PEMBAHASAN}

Penelitian ini bertujuan untuk mengetahui pengaruh profesionalisme pemeriksa pajak secara parsial terhadap kinerja pemeriksa pajak, pengaruh pengalaman kerja pemeriksa pajak secara parsial terhadap kinerja pemeriksa pajak, pengaruh komitmen organisasi pemeriksa pajak secara parsial terhadap kinerja 
pemeriksa pajak, pengaruh profesionalisme, serta pengalaman kerja dan komitmen organisasi pemeriksa pajak secara simultan terhadap kinerja pemeriksa pajak pada Kantor Pelayanan Pajak Pratama Bulukumba. Dengan merujuk pada haril penelitian, masing-masing tujuan penelitian dibahas sebagai berikut:

Pengaruh profesionalisme pemeriksa pajak terhadap kinerja pemeriksa pajak dihitung dengan menggunakan hasil perhitungan koefisien regresi. Dari hasil perhitungan analisis regresi yang dilakukan diperoleh koefisien regresi profesionalisme pemeriksa pajak $\left(\mathrm{X}_{1}\right)$ sebesar 0,209. Angka koefisien regresi tersebut bernilai positif terhadap kinerja pemeriksa pajak (Y). Dengan demikian, dapat dikatakan bahwa semakin baik atau semakin tinggi profesionalisme pemeriksa pajak, maka semakin tinggi atau semakin baik kinerja pemeriksa pajak.

Hasil penelitian ini sejalan dengan penelitian yang dikemukakan oleh Cahyani (2010) bahwa profesionalisme pemeriksa pajak berpengaruh positif dan signifikan terhadap kinerja pemeriksa pajak. Hasil penelitian ini tidak sejalan dengan penelitian yang dilakukan oleh Avianda (2014) pada kantor pajak di wilayah Kantor Wilayah Direktorat Jenderal Pajak Jakarta Timur dan Desiyanti et al. (2019) pada Kantor Pelayanan Pajak Madya Denpasar dan Kantor Pelayanan Pajak Pratama Denpasar Timur, yang menyatakan bahwa profesionalisme pemeriksa pajak tidak berpengaruh secara signifikan terhadap kinerja pemeriksa pajak. Hasil Penelitian ini juga memperkuat dan mendukung penelitian yang dilakukan oleh Faries dan Budiono (2014), Yobi dan Putra (2017) serta Matheus (2018) yang menunjukkan bahwa profesionalisme pemeriksa pajak mempunyai pengaruh signifikan terhadap kinerja pemeriksa pajak.

Pengaruh pengalaman kerja pemeriksa pajak terhadap kinerja pemeriksa pajak dihitung dengan menggunakan hasil perhitungan koefisien regresi. Dari hasil perhitungan analisis regresi yang dilakukan diperoleh koefisien regresi pengalaman kerja pemeriksa pajak $\left(\mathrm{X}_{2}\right)$ sebesar 0,569. Angka koefisien regresi tersebut bernilai positif terhadap kinerja pemeriksa pajak (Y). Dengan demikian, dapat dikatakan bahwa semakin baik atau semakin banyak pengalaman kerja pemeriksa pajak, maka semakin tinggi atau semakin baik kinerja pemeriksa pajak.

Hasil penelitian ini sejalan dengan penelitian yang dikemukakan oleh Misral dan Pratama (2018) bahwa pengalaman kerja pemeriksa pajak berpengaruh positif dan signifikan terhadap kinerja pemeriksa pajak. Hasil penelitian ini tidak sejalan dengan penelitian yang dilakukan oleh Simbolon dan Sumadi (2013) pada Kantor Pelayanan Pajak Pratama Denpasar Timur dan Kantor Pelayanan Pajak Pratama Badung Selatan serta Siahaan (2015) 
pada Kantor Pelayanan Pajak Madya Pekanbaru dan Kantor Pelayanan Pajak Madya Batam, yang menyatakan bahwa pengalaman kerja pemeriksa pajak tidak berpengaruh secara signifikan terhadap kinerja pemeriksa pajak. Hasil Penelitian ini juga memperkuat dan mendukung penelitian yang dilakukan oleh Kotur dan Anbazhagan (2014), Bili et al. (2018), Leatemia (2018) dan Paat et al. (2019) yang menunjukkan bahwa pengalaman kerja pemeriksa pajak mempunyai pengaruh signifikan terhadap kinerja pemeriksa pajak.

Pengaruh komitmen organisasi pemeriksa pajak terhadap kinerja pemeriksa pajak dihitung dengan menggunakan hasil perhitungan koefisien regresi. Dari hasil perhitungan analisis regresi yang dilakukan diperoleh koefisien regresi komitmen organisasi pemeriksa pajak $\left(\mathrm{X}_{3}\right)$ sebesar 0,584. Angka koefisien regresi tersebut bernilai positif terhadap kinerja pemeriksa pajak (Y). Dengan demikian, dapat dikatakan bahwa semakin tinggi komitmen organisasi pemeriksa pajak, maka semakin tinggi atau semakin baik kinerja pemeriksa pajak.

Hasil penelitian ini sejalan dengan penelitian yang dikemukakan oleh Arwati dan Hanifah (2010) bahwa komitmen organisasi pemeriksa pajak berpengaruh positif dan signifikan terhadap kinerja pemeriksa pajak. Hasil penelitian ini tidak sejalan dengan penelitian yang dilakukan oleh Avianda (2014) pada kantor pajak di wilayah Kantor Wilayah Direktorat
Jenderal Pajak Jakarta Timur dan Desiyanti et al. (2019) pada Kantor Pelayanan Pajak Madya Denpasar dan Kantor Pelayanan Pajak Pratama Denpasar Timur, yang menyatakan bahwa komitmen organisasi pemeriksa pajak tidak berpengaruh secara signifikan terhadap kinerja pemeriksa pajak. Hasil Penelitian ini juga memperkuat dan mendukung penelitian yang dilakukan oleh Apriliana et al. (2013), Respatiningsih dan Sudirjo (2015) serta Nurhaida dan Sulastri (2019) yang menunjukkan bahwa komitmen organisasi pemeriksa pajak mempunyai pengaruh signifikan terhadap kinerja pemeriksa pajak pajak.

Pengaruh profesionalisme, pengalaman kerja dan komitmen organisasi secara simultan terhadap kinerja pemeriksa pajak dihitung dengan menggunakan hasil perhitungan koefisien determinasi. Dari hasil perhitungan analisis regresi yang dilakukan diperoleh koefisien determinasi sebesar 0,904 atau 90,4\%. Angka koefisien determinasi tersebut menunjukkan adanya pengaruh positif pada faktor profesionalisme, pengalaman kerja dan komitmen organisasi secara simultan dalam menjelaskan kinerja pemeriksa pajak sebesar 0,904 atau $90,4 \%$, sedangkan sisanya sebesar 0,096 atau $9,6 \%$ dijelaskan oleh variabel lain yang tidak diteliti dalam penelitian ini.

Hasil penelitian ini menunjukkan bahwa kinerja pemeriksa pajak pada Kantor Pelayanan Pajak Pratama Bulukumba akan meningkat 
seiring dengan semakin tingginya profesionalisme pemeriksa pajak, semakin baiknya atau semakin banyaknya pengalaman kerja pemeriksa pajak, serta dengan semakin tingginya komitmen organisasi dari pemeriksa pajak pada Kantor Pelayanan Pajak Pratama Bulukumba.

Untuk meningkatkan profesional-isme pemeriksa pajak, pihak pimpinan Kantor Pelayanan Pajak Pratama Bulukumba sebaiknya selalu mempertahankan profesionalisme pemeriksa pajak dalam melaksanakan tugas pemeriksaan pajak. Pihak pimpinan Kantor Pelayanan Pajak Pratama Bulukumba agar memberikan kesempatan kepada pemeriksa pajak untuk mengembangkan potensi dan kemampuan yang dimiliki. Selain itu, juga diperlukan pengawasan internal dari pimpinan untuk mengawasi pemeriksa pajak agar selalu menjaga integritas dan bekerja secara profesional sesuai dengan kode etik dari pemeriksa pajak. Dengan terciptanya kondisi tersebut pada Kantor Pelayanan Pajak Pratama Bulukumba, maka tingkat profesionalisme pemeriksa pajak pada Kantor Pelayanan Pajak Pratama Bulukumba akan semakin meningkat.

Untuk mewujudkan terciptanya peningkatan pengalaman kerja pemeriksa pajak, pihak Kantor Pelayanan Pajak Pratama Bulukumba sebaiknya secara berkala melaksanakan forum komunikasi untuk pemeriksa pajak, yang bertujuan untuk memberikan wadah kepada pemeriksa pajak untuk berbagi pengalaman kepada pemeriksa pajak lainnya dalam menyelesaikan kasus pemeriksaan pajak, baik untuk kasus pemeriksaan pajak yang dilaksanakan pada Kantor Pelayanan Pajak Pratama Bulukumba maupun pada Kantor Pelayanan Pajak sebelumnya. Hal ini juga akan memberikan pengetahuan kepada pemeriksa pajak yang baru dan belum memiliki banyak pengalaman dalam menangani kasus pemeriksaan pajak. Dengan terciptanya kondisi tersebut pada Kantor Pelayanan Pajak Pratama Bulukumba, maka akan menambah pengalaman kerja pemeriksa pajak pada Kantor Pelayanan Pajak Pratama Bulukumba.

Untuk mewujudkan terciptanya tingkat komitmen organisasi yang tinggi pada pemeriksa pajak, pimpinan pada Kantor Pelayanan Pajak Pratama Bulukumba sebaiknya menciptakan hubungan kerja yang harmonis antar sesama pegawai. Pihak pimpinan Kantor Pelayanan Pajak Pratama Bulukumba agar memberikan penghargaan kepada pegawai dalam hal ini pemeriksa pajak yang memiliki kinerja yang baik, sesuai dengan ketentuan yang berlaku. Dengan terciptanya kondisi tersebut, maka komitmen organisasi pada Kantor Pelayanan Pajak Pratama Bulukumba akan semakin meningkat.

Dengan semakin tingginya tingkat profesionalisme pemeriksa pajak, dan semakin baik atau semakinbanyaknya pengalaman kerja pemeriksa pajak, serta dengan semakin tinggi tingkat komitmen organisasi pemeriksa pajak, 
maka akan semakin tinggi pula tingkat kinerja pemeriksa pajak pada Kantor Pelayanan Pajak Pratama Bulukumba.

\section{KESIMPULAN DAN SARAN}

Berdasarkan hasil penelitian dan pembahasan diperoleh kesimpulan bahwa profesionalisme, pengalaman kerja dan komitmen organisasi berpengaruh positif terhadap kinerja pemeriksa pajak pada Kantor Pelayanan Pajak Pratama Bulukumba, baik secara parsial maupun secara simultan. Adapun saran yang bisa diberikan dalam penelitian ini adalah saran kepada pemeriksa pajak, pimpinan Kantor Pelayanan Pajak Pratama Bulukumba dan penelitian selanjutnya. Bagi pemeriksa pajak, disarankan untuk selalu meningkatkan profesionalisme dalam melaksanakan tugas pemeriksaan, seperti menyelesaikan pemeriksaan tidak melewati jangka waktu yang telah ditentukan, menyusun temuan pemeriksaan dengan dasar hukum yang kuat, serta selalu menjaga integritas dalam menjalankan tugas dan profesinya. Pemeriksa pajak juga disarankan untuk selalu berbagi pengalaman kepada pemeriksa lainnya, serta selalu meningkatkan komitmen dan loyalitas terhadap organisasi. Bagi pimpinan pada Kantor Pelayanan Pajak Pratama Bulukumba, disarankan untuk selalu mempertahankan sikap profesionalisme pemeriksa pajak dalam melaksanakan tugas, agar pemeriksaan pajak dapat berjalan dengan lancar dari awal hingga akhir, sesuai dengan ketentuan yang berlaku. Pimpinan Kantor Pelayanan Pajak Pratama Bulukumba agar rutin melakukan monitoring dan evaluasi terhadap progres penyelesaian pemeriksaan yang dikerjakan oleh pemeriksa pajak. Pihak Kantor Pelayanan Pajak Pratama Bulukumba juga disarankan untuk meningkatkan pelaksanaan forum komunikasi pemeriksa pajak, sebagai forum untuk berbagi pengalaman antar pemeriksa pajak yang memiliki banyak pengalaman dengan pemeriksa pajak lainnya. Forum ini juga bisa dijadikan sebagai sarana untuk meningkatkan komitmen organisasi pemeriksa pajak, sehingga pemeriksa pajak menjadi semakin loyal terhadap organisasi, dalam hal ini Kantor Pelayanan Pajak Pratama Bulukumba. Pimpinan Kantor Pelayanan Pajak Pratama Bulukumba juga sebaiknya memberikan penghargaan terhadap peningkatan kinerja pemeriksa pajak, serta memperhatikan peningkatan jenjang karir dari pemeriksa pajak tersebut. Bagi penelitian selanjutnya, disarankan untuk melakukan penelitian dengan menambah variabel lain yang tidak digunakan dalam penelitian ini, seperti motivasi kerja, kompensasi finansial, stress kerja atau variabel lainnya, ataupun dengan memperluas ruang lingkup penelitian dengan menggunakan sampel dari Kantor Pelayanan Pajak lainnya yang dapat digunakan sebagai sampel. 


\section{REFERENSI}

Apriliana, Sarrah, D. Hamid dan M.S. Hakam. 2013. Pengaruh Motivasi dan Komitmen Organisasional Terhadap kinerja Karyawan. Jurnal Administrasi Bisnis (JAB). 1 (1). p 180-187 [online].

Arwati, Dini dan Hanifah. 2010. Pengaruh Komitmen Organisasi Pemeriksa Pajak Dalam Meningkatkan Kinerja Pemeriksa Pajak (Survey di Wilayah Direktorat Pajak Jawa Barat I). Jurnal Bisnis, Manajemen \& Ekonomi. 9 (10). p 2341-2351 [online].

Arikunto, Suharsini. 2002. Prosedur Penelitian, Pendekatan Praktek. Jakarta: Rineka Cipta.

Avianda, Kindi. 2014. Pengaruh Profesionalisme Pemeriksa Pajak, Kepuasan Kerja, Komitmen Organisasi dan Motivasi Kerja Terhadap Kinerja Karyawan. Media Riset Akuntansi, Auditing \& Informasi. 14 (3). p 21-48 [online].

Bili, Wanceslaus, E. Resmawan dan D. Kondorura. 2018. Pengaruh Pengalaman Kerja Terhadap Kinerja Pegawai di Kantor Kecamatan Laham Kabupaten Mahakam Ulu. eJournal Pemerintahan Integrattif. 6 (3). p 465-474 [online].

Cahyani, Nur. 2010. Pengaruh Profesionalisme Pemeriksa Pajak, Kepuasan Kerja dan Komitmen Organisasi Terhadap Kinerja Karyawan. Jurnal Bisnis dan Ekonomi (JBE). 17 (1). p 10-23 [online].

Desiyanti, N.M. Indri, I.W.S. Negara dan N.W. Yuniasih. 2019. Pengaruh Pelatihan, Motivasi Kerja, Profesionalisme, dan Komitmen Organisasi Pada Kinerja Account Representative (Studi di Kantor Pelayanan Pajak Madya Denpasar dan Pratama Denpasar Timur). Jurnal Riset Akuntansi JUARA. 9 (1). p 19-27 [online].
Faries, Feliana dan D. Budiono. 2014. Pengaruh Perilaku Pemeriksa Pajak dan Profesionalisme Pemeriksa Pajak Terhadap Kinerja Pemeriksa Pajak (Survei pada Konsultan Pajak Surabaya). Tax \& Accounting Review. 4 (1). p 1-11 [online].

Fatah, M. Abdul, A. Wiratno dan A.P. Ompusunggu. 2017. Pengaruh Independensi, Pengalaman, Profesionalisme, dan Komitmen Organisasi Pemeriksa Pajak terhadap Kualitas Audit Pajak di Kanwil DJP Jakarta Khusus. Jurnal Riset Akuntansi dan Perpajakan JRAP. 4 (2). p 149-161 [online].

Ibrahim, E. Cahaya dan R.A. Arum. 2018. Kepatuhan Sukarela Wajib Pajak Dalam Pelakasanaan Tax Amnesty pada Kantor Pelayanan Pajak (KPP) Pratama Makassar Utara. Jurnal Administrasi Negara. 24 (2). p 89-100 [online].

Kotur, B.R. dan S. Anbazhagan. 2014. Education and Work-Experience - Influence on the Performance. IOSR Journal of Business and Management. 16 (5). p 104-110 [online].

Leatemia, S. Yunita. 2018. Pengaruh Pelatihan dan Pengalaman Kerja Terhadap Kinerja Pegawai (Studi pada Kantor Badan Pusat Statistik di Maluku). Jurnal Manis. 2 (1). p 1-10 [online].

Matheus, Evan. 2018. Pengaruh Profesionalisme, Kepuasan Kerja, Motivasi, dan Lingkungan Kerja Terhadap Kinerja Pemeriksa Pajak (Studi pada Pemeriksa Pajak KPP Pratama Bangkinang, KPP Pekanbaru Senapelan, KPP Pratama Pekanbaru Tampan, dan KPP Madya Pekanbaru). JOM FEB. 1 (1). p 1-14 [online].

Misral dan A. Pratama. 2018. Pengaruh Kompensasi Finansial, Pengalaman Kerja, Pelatihan Kerja dan Stres Kerja Terhadap Kinerja Pemeriksa Pajak. 
Jurnal Akuntansi \& Ekonomika. 8 (1). p 128-134 [online].

Moeheriono. 2012. Pengukuran Kinerja Berbasis Kompetensi. Jakarta: Raja Grafindo Persada.

Nurhaida dan Susilastri. 2019. Pengaruh Budaya Organisasi, Kepuasan Kerja dan Komitmen Organisasi Terhadap Kinerja Pegawai di Pemerintahan Kota Padang Panjang. MENARA Ilmu LPPM UMSB. 13 (6). p 163-170 [online].

Paat, F. Armando, Adolfina dan R.T. Saerang. 2019. Analisis pengalaman kerja dan stres kerja serta pengaruhnya terhadap kinerja karyawan PT. Air Manado. Jurnal EMBA. 7 (1). p 241-250 [online].

Ratulangi, R.S. dan A.S. Soegoto. 2016. Pengaruh Pengalaman Kerja, Kompetensi, Motivasi Terhadap Kinerja Karyawan (Studi pada PT. Hasjrat Abadi Tendean Manado). Jurnal EMBA. 4 (4). p 322-334 [online].

Respatiningsih, Ida dan F. Sudirjo. 2015. Pengaruh Komitmen Organisasi, Motivasi, Kapabilitas dan Kepuasan Kerja Terhadap Kinerja Pegawai (Studi Empirik Pada Inspektorat Kabupaten Pemalang). Serat Acitya - Jurnal Ilmiah UNTAG Semarang. 4 (3). p 56-68 [online].

Sedarmayanti. 2010. Reformasi Administrasi Publik, Reformasi Birokrasi, dan Kepemimpinan Masa Depan. Bandung: PT Refika Aditama.

Siahaan, E. Natalia. 2015. Pengaruh Pengalaman Kerja, Stres Kerja, Kompensasi Finansial, dan Lingkungan Kerja Terhadap Kinerja Pemeriksa Pajak (Studi Empiris pada Pemeriksa Pajak di KPP
Madya Pekanbaru dan KPP Madya Batam). Jom FEKON. 2 (2). p 1-16 [online].

Simbolon, T.I. Maranatha dan I.K. Sumadi. 2013. Faktor-Faktor Yang Mempengaruhi Kinerja Pemeriksa Pajak di KPP Pratama Denpasar Timur dan Badung Selatan. E-Jurnal Akuntansi Universitas Udayana. 3 (3). 198-215 [online].

Suparyadi, H. 2015. Manajemen Sumber Daya Manusia Menciptakan Keunggulan Bersaing Berbasis Kompetensi SDM. Edisi ke-1. Yogyakarta: Penerbit ANDI.

Yobi, N.M.D. Juni dan I.N.W.A. Putra. 2017. Faktor-Faktor Yang Mempengaruhi Kinerja Account Representative di KPP Pratama Gianyar, Tabanan, Dan Singaraja. E-Jurnal Akuntansi Universitas Udayana. 20 (3). p 2449-2478 [online].

Waterkamp, C.I.A, H. Tawas dan C. Mintardjo. 2017. Pengaruh Profesionalisme, Komitmen Organisasi dan Kepuasan Kerja Terhadap Kinerja Karyawan pada PT. Bank Rakyat Indonesia (Persero) Cabang Manado. Jurnal EMBA. 5 (2). p 2808-2818 [online]. 